\title{
ANTHROPOGENIC IMPACTS ON CORAL REEFS AND THEIR EFFECT ON FISHERY OF KILWA DISTRICT, TANZANIA \\ *MBIJE, N.E. ${ }^{1}$ and RINKEVICH, B. ${ }^{2}$ \\ http://dx.doi.org/10.4314/ejesm.v6i5.1
}

Received 24th October 2012; accepted 12th July 2013

\begin{abstract}
s
Tanzanian fishing coastal communities live on fishing activities as one their major economic activities, practicing fishing on shallow coral reefs areas whereby about $70 \%$ of fishery is artisanal. Improper use and overexploitation of fishery resources have resulted in damaging the coral reefs and the subsequent low quality catches. This study aimed at examining the impacts of coral reef fishery decline on rural livelihoods with an emphasis on food insecurity, alternative capabilities and activities on coastal communities of Kilwa district, Tanzania. Data collection methodology included household questionnaire survey, key informant interviews, participant observation and photographing. The survey was based on a sample of 90 households, randomly selected from three villages. The findings attest for a gradual reduction in fish catches over time, brought about by natural and anthropogenic impacts. Overfishing, use of illegal and destructive fishing methods, as well as extreme weather conditions, all threaten the sustainability of marine resources, particularly coral reef fishery that constitutes an important source of food and livelihood. Following the results and as a way of lessen the current pressure on marine resources and diversifying livelihood capabilities we recommend introduction of mariculture and modern farming technologies especially on green vegetables on farms that can potentially be irrigated. The study further recommends establishment of a marine protected area and; in addition, the need to promote educational programs on environmental and resources uses as well as application of active restoration protocols for damaged coral reefs.
\end{abstract}

Key words: Songo songo, Kivinje, Songo mnara, livelihoods, coral bleaching

\section{Introduction}

A third of Tanzania's population live at coastal areas occupying $22 \%$ of the $881,289 \mathrm{~km}^{2}$ of mainland Tanzania (NBS, 1999). Besides practicing subsistent agriculture, they rely on exploitation of natural resources, fishing, being most important (Jiddawi, 1997). The largely non- mechanised agricultural activities are seasonal and strongly influenced by rain patterns, involving mostly women, (Mwichande, 2001). In contrast, fishing activities are conducted throughout the year acting a major source of food that supplies $90 \%$ of consumed animal protein and the perpetual, year-round source of income (Wagner, 2005). Most fishery activities are practiced within a narrow range of shallow water along the coastal areas that include sea grass beds, mangrove and coral reefs (Jiddawi and Öhman, 2002; Wagner, 2004).
Fisheries in coral reefs involve harvesting of fish and shellfish for food and collection of merchandise for the curio and aquarium trades. On the other hand, reef associated tourism brings foreign currency into the country, establishing improved livelihoods for coastal people through employment and costs of services (Andersson, 1998).

Conversely, in recent times reefs have been declining at an alarming rate thus threatening fisheries integrity of the coastal communities. It is estimated that global coral reef decline associate with ocean acidification, warming, pollution and overfishing has reached 125, 000 square kilometres (Hoegh-Guldberg and Bruno, 2010) and continues to increase. The decline due to overfishing and using bad fishing practices are common in developing world including Tanzania (Guard and Massaiganah 1998; Wilkinson, 2004;

${ }^{1}$ Sokoine University of Agriculture, Faculty of Forestry

\& Nature Conservation, Wildlife Management

Department, P.O. Box 3073, Morogoro Tanzania

${ }^{2}$ Israel Oceanographic and Limnological Research,

National Institute of Oceanography, Tel-Shikmona,

P.O.B. 8030, Haifa 31080, Israel

*Corresponding author: mbije@yahoo.com 
Souter and Linden, 2005; Mbije et al., 2010; 2013). Furthermore, the current climate changes associated with unpredictability of rains for agriculture have forced local communities to either intensify fishing or migrate for alternative livelihood within or outside their native areas (Mwamsojo, 2000). Following the above, the main objective of this study was to understand the scope and magnitude of human induced coral reef fisheries decline in Kilwa District, Tanzania and its implication on local livelihoods, followed by suggesting strategies for solutions to improve the welfare of the fishing communities.

\section{Methodology}

\section{Description of the Study Site}

This study was conducted in three coastal fishing villages namely; Kilwa Kivinje, Songo Mnara and Songo songo found in Kilwa district located in south-eastern region of Lindi region in Tanzania (Figure 1). Songo Mnara is located on the southern part of Kilwa coastline whereas
Kilwa Kivinje is centrally located. Songo songo is an island within the vast Kilwa archipelago. The major economic activity in these villages is fishing, supported by agriculture at subsistent level (Ngoile et al., 2001; Mwichande, 2001). Besides terrestrial vegetation that form continuum of the mostly Acacia sp. traversing into hinterland, there are extensive mangrove forests covering 22, 438.7 ha, from Mohoro Bay at the border of Rufiji district to Mzungu Bay bordering Lindi district (Semesi et al., 1991). These mangrove form important breeding and nursery grounds for both marine and terrestrial fauna, including some commercially important species such as sardines (Rastrelliger kanagurta), catfishes (Ariidae), milkfish (Chanos chanos), goatfish (Mullidae), apogionidae, clupeidae, crabs and molluscs (Semesi et al., 1991).

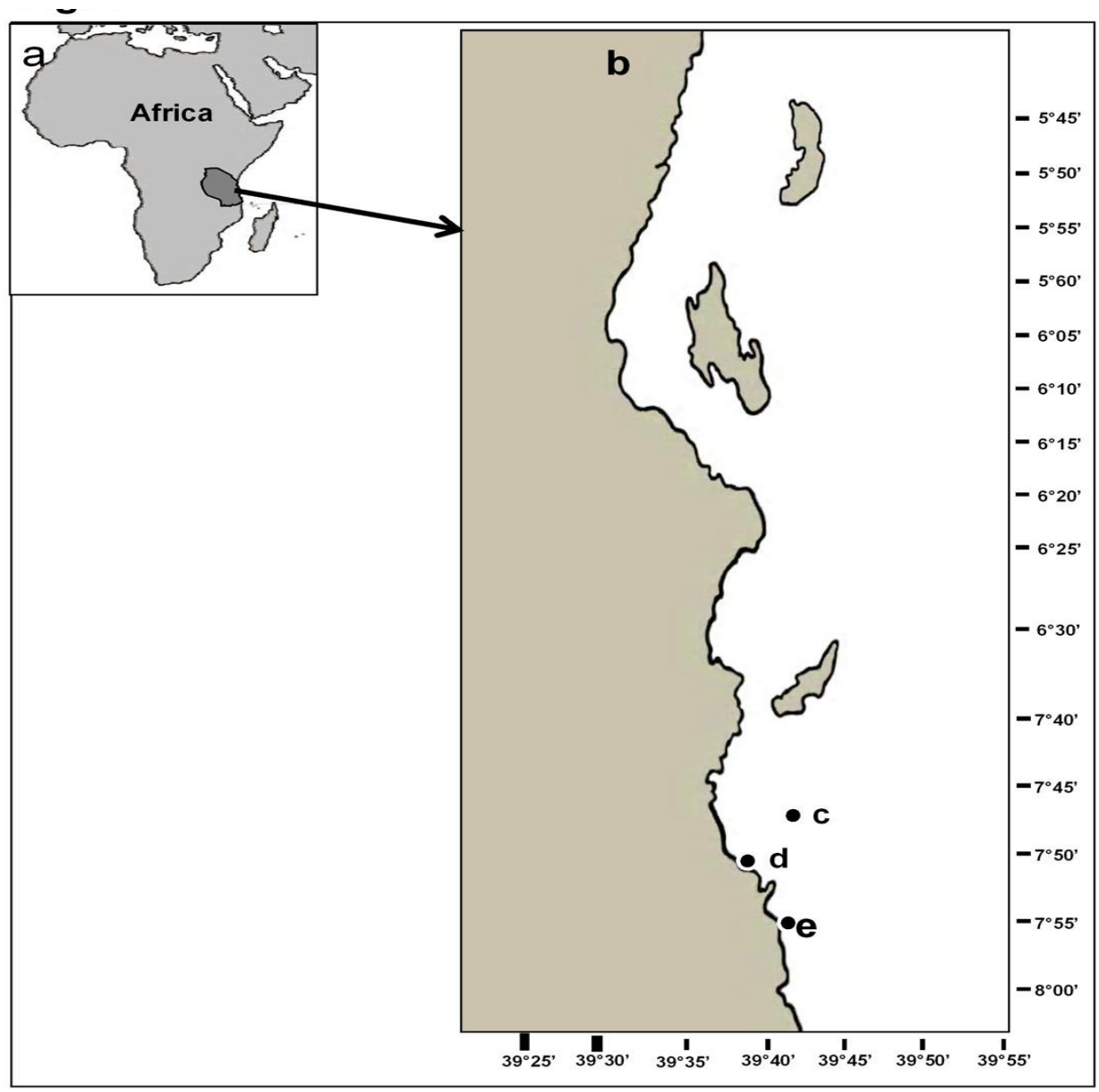

Figure 1. Map of Tanzania showing (a) Tanzania (Africa insert), (b) Tanzanian coastline (c, d, e) Songo songo, Kilwa Kivinje and Songo Mnara study sites, respectively.

Coral reefs of Kilwa are mostly fringing, forming complex tropical shallow water ecosystems with high biodiversity (Wagner,
2004). These reefs are found within a complex island archipelago (including Ukuza, Songo songo, Sanje ya Kati, Songo Mnara, Nyuni, 
Fanjove, Limbi, Kilwa Kisiwani, Amana, Mwanakayo, Fungu Wango, Mpovi and Kiswasi); some of them inhabited by human population. The diversity of corals in these reefs is one of the highest in East Africa whereby, like many other reefs, the dominant coral species are Porites spp, Favia spp, Pavona spp, Montipora spp, Millepora spp, Acropora spp., Galaxea spp. and Favites spp (Mbije et al, 2002).

\section{Data Collection}

Household survey was conducted in the three study villages, Kivinje, Songo songo and Songo Mnara (Figure 1). Purposive sampling was used to select the study villages based on accessibility and position. Kivinje was chosen as representing a relatively developed urban area, Songo songo represented islands and Songo Mnara as representing isolated fishing villages, common along Kilwa coastline, away of large markets urban areas. The village registers from the three villages were used as a sampling frame. Ninety households, representing $10 \%$ of the total households for the three villages, were randomly selected for this survey. A questionnaire was administered to participants for data collection. The questionnaire included questions on type of fishing gears used, fishing methods, types of fishing grounds, content and quantities of fish catches, quantities sold and revenue from their sale, total household income, percentage contribution of fishing products to total income, trends in fishing comparing period before and after 1997/98 massive coral bleaching, fishing constraints, fishing trends and climate change effects. In addition, direct observations were conducted in various locations to appreciate types of fishing vessels, fishing gears, contents of catches at fish markets, crops grown and general life styles of the communities in the three selected villages.

Focus group discussions were held with villages officials, district natural personnel and agriculture officers to get their views on trends of fishing, caught fish species and their contribution in revenue earning, patterns in agriculture as well as management challenges of resources.Secondary data were obtained by reviewing literature on Kilwa district's coral reefs, mangrove, sea grass and fishery. The documents reviewed included Mangrove Management Project report (MMP, 2003); Fisheries Regulation Act (URT, 2005); Guideline for Collaborative Management of Marine Resources of Kilwa District (WWF-
RUMAKI, 2009); Collaborative Fisheries Management (CFM) monitoring plans for Rufiji, Mafia, Kilwa Fishing communities (WWF, 2008) and the Annual District Fisheries Reports (2001-2009) .

Data Analysis

Statistical Package for Social Sciences (SPSS) was used to analyze the primary quantitative data collected by using a questionnaire whereas content analysis was used for analyzing qualitative data obtained from the unstructured interviews, focus group discussion, documents review and observation. The qualitative data was sorted and categorized into meaningful themes in keeping with the objectives of this study.

\section{Results and Discussion \\ Demographic characteristics of respondents}

The majority $(93.3 \%)$ of the respondents were males with only $6.7 \%$ females, two thirds of these $(66.7 \%)$ being native to their respective villages (Table 1$)$. The majority $(90 \%)$ of nonnatives $(n=81)$ immigrated from Mtwara and other parts of Lindi regions, mainly for the purpose of looking for alternative livelihoods. The abundance of natural resources available within the district, availability of fertile land and the reliability of rains were cited as factors for immigration (Mwichande, 2001).

Table 1 Respondents' place of birth

\begin{tabular}{lll}
\hline Villages & Native (\%) & Immigrant (\%) \\
\hline Songosongo & 25.6 & 7.8 \\
KilwaKivinje & 22.2 & 11.1 \\
SongoMnara & 18.9 & 14.4 \\
Total & 70.0 & 30.0 \\
\hline
\end{tabular}

Before the construction of the bridge across Rufiji River and the tarmac road from Dar es Salaam to Mtwara, Kilwa was the Tanzanian southernmost district that was easily reached mainly through the seasonal road by crossing Rufiji River at Ndundu ferry. This contributed in making the district more vibrant economically thus attracting immigrants. The various goods shipped from this area to northern markets of Tanzania, mainly Dar es Salaam and Zanzibar includes forestry, fishery and some agricultural products (Annual District Fisheries Reports, 2001).

\section{Poverty and its indicators in the study villages}

We used 'poverty' as the major characteristic to describe households' socioeconomic status in relation to access or use of 
natural resources. Poverty was attributed to tive indicators: (i) household food, (ii) income insecurity (iii) household assets and material life styles (iv) household literacy, and (v) health wellbeing. With guidance from village leaders we defined three wealth groups, poor, rich, and very rich. In order to relate between poverty in individual villages and ownership of fishing assets, data on fishing gear and fishing vessels were cross-tabulated against the data on economic status of the households (Table 2).

Fishing gears that required heavy capital investment (starting from 3 million Tanzanian shillings) were few (row 4 and 8) when compared to among the more popular hand lines and fencing used by the low income individuals (Table 2: rows 3 and 5). Thus outboard engines were owned by a few individuals while the canoes and sail boats were shared between the low income and the rich (rows 6 and 7). The canoes are easily made out from mangroves that readily available in the area.

Considering types of fishing gear as poverty indicator, comparison across villages revealed that poverty was more prevalent in Songo Mnara where fishermen did not have a single outboard engine, or any ringnets but possessed several low cost fishing gears. Studies by Francis et al. (2001) and Wagner (2004) indicate that one of the main underlining root causes of degradation in marine environments in Tanzania is poverty. Correspondingly, some of the lower quality gears are responsible for marine environment degradation through intensification of fishing in the same areas thus leading to over-exploitation.

Table 2 Types and number of fishing gears possessed by fishermen in the three villages

\begin{tabular}{|c|c|c|c|c|c|c|c|c|c|c|c|}
\hline & \multirow[t]{2}{*}{ Item } & \multirow[t]{2}{*}{ Total } & \multicolumn{3}{|c|}{ SongoSongo } & \multicolumn{3}{|c|}{ KilwaKivinje } & \multicolumn{3}{|c|}{ SongoMnara } \\
\hline & & & Poor & Average & rich & Poor & Average & Rich & Poor & Average & Rich \\
\hline \multirow[t]{2}{*}{1} & Seine nets & Count & 22 & 21 & 20 & 19 & 34 & 18 & 6 & 8 & 13 \\
\hline & & $\%$ & 34.9 & 33.3 & 31.7 & 26.7 & 47.8 & 25.3 & 22.2 & 29.6 & 48.1 \\
\hline \multirow[t]{2}{*}{2} & Shark nets & Count & 54 & 84 & 20 & 43 & 60 & 62 & 3 & 11 & 13 \\
\hline & & $\%$ & 34.1 & 53.1 & 12.6 & 26.1 & 36.4 & 37.5 & 11.1 & 40.7 & 48.1 \\
\hline \multirow[t]{2}{*}{3} & Hand lines & Count & 460 & 50 & 0 & 550 & 0 & 27 & 200 & 10 & 18 \\
\hline & & $\%$ & 90.1 & 8.9 & 0 & 95.3 & 0 & 4.7 & 87.7 & 4.2 & 7.8 \\
\hline \multirow[t]{2}{*}{4} & Ring nets & Count & 0 & 23 & 15 & 0 & 15 & 20 & 0 & 0 & 0 \\
\hline & & $\%$ & 0 & 60.5 & 39.5 & 0 & 42.8 & 57.2 & 0 & 0 & 0 \\
\hline \multirow[t]{2}{*}{5} & Fencing & Count & 8 & 0 & 0 & 5 & 0 & 0 & 38 & 5 & 10 \\
\hline & & $\%$ & 100 & 0 & 0 & 100 & 0 & 0 & 88.3 & 11.7 & 0 \\
\hline \multirow[t]{2}{*}{6} & Dugout & Count & 41 & 52 & 0 & 34 & 15 & 40 & 26 & 42 & 30 \\
\hline & canoes & $\%$ & 44.0 & 56.0 & 0 & 38.2 & 16.8 & 45 & 26.5 & 42.8 & 30.6 \\
\hline \multirow[t]{2}{*}{7} & Sail boats & Count & 7 & 6 & 7 & 2 & 5 & 14 & 0 & 1 & 2 \\
\hline & & $\%$ & 35 & 30 & 35 & 9 & 23.8 & 66.6 & 0 & 33.3 & 66.6 \\
\hline \multirow[t]{2}{*}{8} & Outboard & Count & 0 & 20 & 22 & 0 & 14 & 22 & 0 & 0 & 0 \\
\hline & Engines & $\%$ & 0 & 47.6 & 52.3 & 0 & 38.8 & 62.2 & 0 & 0 & 0 \\
\hline
\end{tabular}

\section{Major livelihoods strategies in the study villages}

In the study area, most respondents (93.3\%) in the surveyed villages are engaged with fishing activities (Figure 2). Further analysis of the three villages revealed high variation in income from fishing activities (Table 3 ).

Generally, as majority of the surveyed participants relied on fishing as their main income, Songo Songo Island was more dependent on fishing compared to the Kilwa Kivinje and Songo Mnara (Table 3). This could be related to the geography of the villages, as it is about $12 \mathrm{~km}$ off the coastline from Kilwa Kivinje where option for other activities than fishing is limited. Further analysis of data revealed that, $68.9 \%$ of the households preferred using coral reef areas as their main fishing grounds, whereas $31.1 \%$ preferred using nonreef areas (Table 4). 
Table 3 Percentage income derived from fishing activities

\begin{tabular}{llllll} 
Villages & Don't know & $0-25 \%$ & $26-50 \%$ & $51-75 \%$ & Above 75\% \\
\hline Songosongo & 14.4 & 24.3 & 15.1 & 15.2 & 30.1 \\
KilwaKivinje & 27.7 & 25.5 & 10.1 & 16.6 & 20.1 \\
SongoMnara & 24.5 & 15.6 & 25.2 & 17.8 & 17.0 \\
\hline
\end{tabular}

Table 4 Percentage preference of the fishing grounds

\begin{tabular}{llc}
\hline Villages & \multicolumn{2}{c}{ Percentages } \\
\cline { 2 - 3 } & Reef Areas & Non Reef Areas \\
Songosongo & 18.8 & 14.4 \\
Kilwa Kivinje & 21.1 & 12.2 \\
Songo Mnara & 28.9 & 4.4 \\
Total & 68.9 & 31.1 \\
\hline
\end{tabular}

This information reflects the importance of coral reefs to fishery of Tanzania and confirms findings by Jiddawi (1997) and Wagner (2004) that majority of fishing communities along the coastline of Tanzania rely on coral reefs as their main fishing grounds. The existence of extensive formation of reefs within the Kilwa Archipelago and their convenient accessibility in most part provides a broad spectrum of areas upon which fishing is practised. Focused group discussion revealed that large schools of tuna

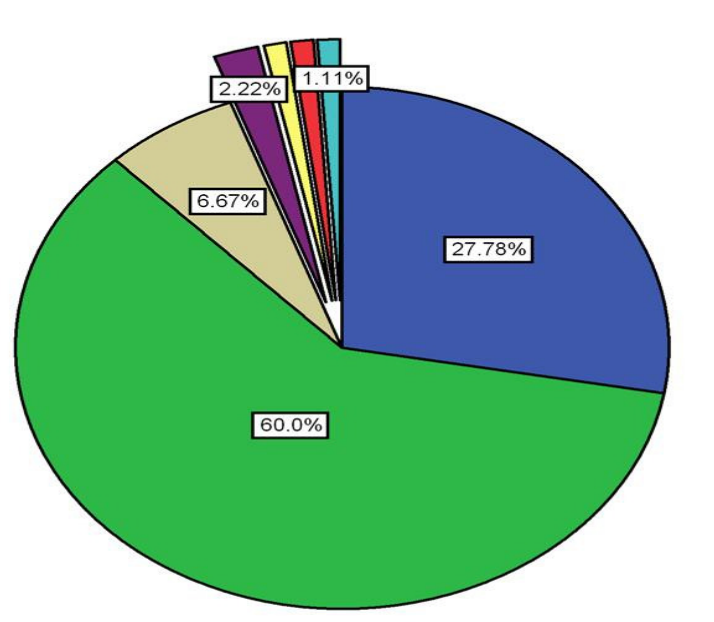

species (Katsuwonus pelamis, Thunnus thynnus and Thunus albacores) and swordfish (Xiphias gladius) are regularly spotted in several islands within the Kilwa archipelago. The small sized pelagic species are also captured at night through the use of hand operated chandeliers (Figure 4b). Further household survey indicated that besides fishing, participants practiced other income generating activities. These include crop farming (60\%), petty business $(27.7 \%)$, and a host of other small activities (Figure 2).

Figure 2 The respondents' alternative livelihood strategies

Kilwa district has about $8,863 \mathrm{~km}^{2}$ of the potential arable land (Appendix 1) and agriculture employs more than $90 \%$ of people contributing 70\% to the District's GDP (Ngoile et al., 2001). During focussed group discussion (FGD) session with local leaders at Kilwa Kivinje and Songo Mnara it was revealed that,

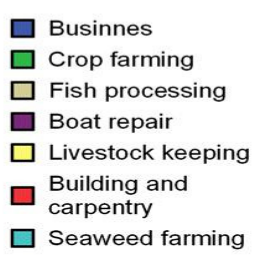

in response to increased demands, many households had recently increased the number of crops cultivated. Traditional crops included sim sim (Sesamum indicum), cashewnuts (Anacardium occidentale), rice (Oryza sativa), maize (Zea may), cassava (Manihot esculenta) and green vegetables (amaranth) but recently 
sweet potatoes and a variety of legumes were adopted. Apparently, the discussions also revealed that agricultural production in recent years has been severely hampered by the unpredictability of rains. A study by Boko et al. (2007) asserts that rains patterns like this usually results in serious food insecurity and destabilisation of social networks, hindering eradication of poverty. On the other hand, a study by Ngoile et al. (2001) showed that the District has about $433.2 \mathrm{~km}^{2}$ potential area for irrigation of which only $8 \mathrm{~km}^{2}$ is being irrigated. This means that intensification of irrigation activities with application of modern farming methods may boost agricultural productivity. Other livelihood activities in the study area included petty businesses, boat making and repair, food vending; locally known as mamalishe, operation of kiosks/shops, bars, tea rooms, fish processing, masonry and carpentry.

Coral reef degradation and its relationship to fishery integrity in Kilwa

During the household interviews, $82.2 \%$ of the participants who were fishermen indicated that the fish catches have steadily declined in the past ten years (Table 5).

Table 5 Respondents' view (\%) on trend in fish catch over the past 10 years

\begin{tabular}{lllll}
\hline Villages & Do not know & Increasing & Decreasing & The same \\
\hline Songosongo & 4.4 & 0 & 25.6 & 3.3 \\
KilwaKivinje & 1.1 & 1.1 & 26.7 & 4.4 \\
SongoMnara & 1.1 & 1.1 & 30.0 & 1.1 \\
Total & 6.6 & 2.2 & 82.3 & 8.8 \\
\hline
\end{tabular}

According to the interviews, commercial fish species that contribute significantly to their total gains but recently show rapid decline include goatfish (Mullidae), angelfish (Pomacanthidae), surgeonfish (Acanthuridae), wrasses (Scaridae) and butterfly (Chaetodintiae). When asked the

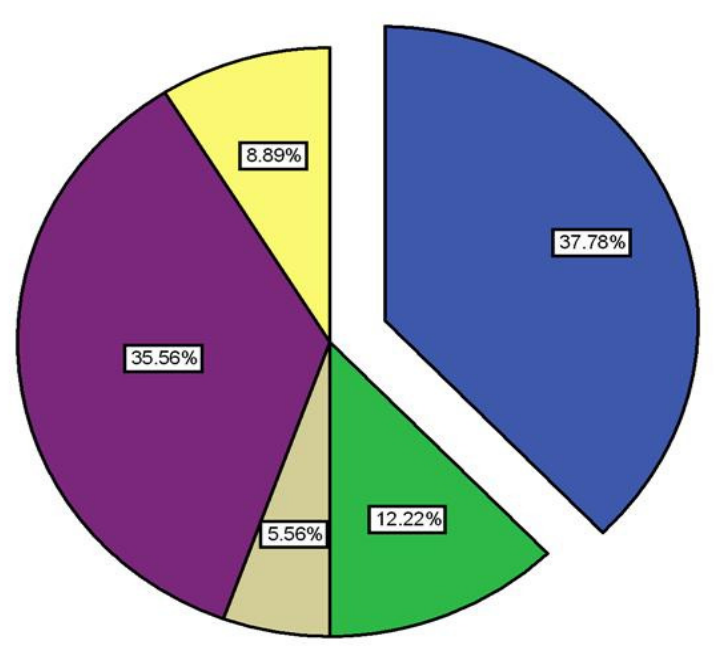

reason for this decline, $35.6 \%$ of the participants attributed it to bad fishing practices that include use of dynamite, small mesh size nets and seine nets; $12.2 \%$ put a blamed on the climate changes; and $8.9 \%$ said it was a combination of the above (Figure 5).

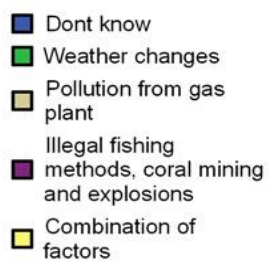

Figure 5 Respondents' view on reasons for the decrease in fisheries catch over the last 10 years

Three factors that promote bad fishing and over-utilization of marine resources were ranked. These were: (i) increased number of fishermen; (ii) Bad and destructive fishing practices; (iii) encroachment of foreign vessel (Table 4). It is considered that the influx of short term fishermen from other parts of Tanzania to be the biggest threats to the sustenance of their fisheries and livelihood general. Additionally, according to the focused group discussion, climate change was responsible for killing corals that provide habitats to fishes thus destabilizing ecosystems. For example, the higher sea surface temperature of 1997/1998 and the associated massive death of coral reefs have been shown to have influenced the decline in fish catches (Lindahl et al., 2001). Overall, the decline in fish catches is becoming more widespread both in Tanzania and Kenya (McClanahan et al., 1999; McClanahan, 1997; Garpe et al., 2003) resulting in major 
socio-economic hardships for poor coastal communities, as a result of declining fishing income

\section{Coping strategies and their consequences to the fishing communities of Kilwa}

Development of alternative livelihoods has become a popular policy to uplift the socioeconomic status of small-scale fishers and to reduce fishing pressure on overexploited fisheries (Crawford, 2002). The interviewed households expressed mixed feelings with regards to diversification of livelihood strategies. Of the total households interviewed, 51.1\% wished to increase alternative livelihood options, whereas $31.0 \%$ thought better fishing gear will solve the problem. Some $14.4 \%$ wanted to move to other remote fishing sites (Table 6).

Table 6 Respondents' views on how to counteract low gain from fisheries

\begin{tabular}{lccl}
\hline & & \multicolumn{2}{c}{ Percentages } \\
\hline Villages & Changes to other & Change in fishing & Diversify alternative \\
& fishing sites & gear & livelihood strategies \\
Songosongo & 6.7 & 7.8 & 18.9 \\
KilwaKivinje & 6.7 & 10.0 & 16.7 \\
SongoMnara & 1.1 & 16.7 & 15.6 \\
Total & 14.5 & 34.4 & 51.1 \\
\hline
\end{tabular}

As difficult as it may be to control damages within the reef and other marine areas because of their vast size and lack of funds, it is high time to think of reducing the pressure by introducing alternative viable livelihoods. Generally there are two main objectives for promotion of alternative livelihood. The first is to raise the economic standard of living of the communities and the second is to reduce resource extraction

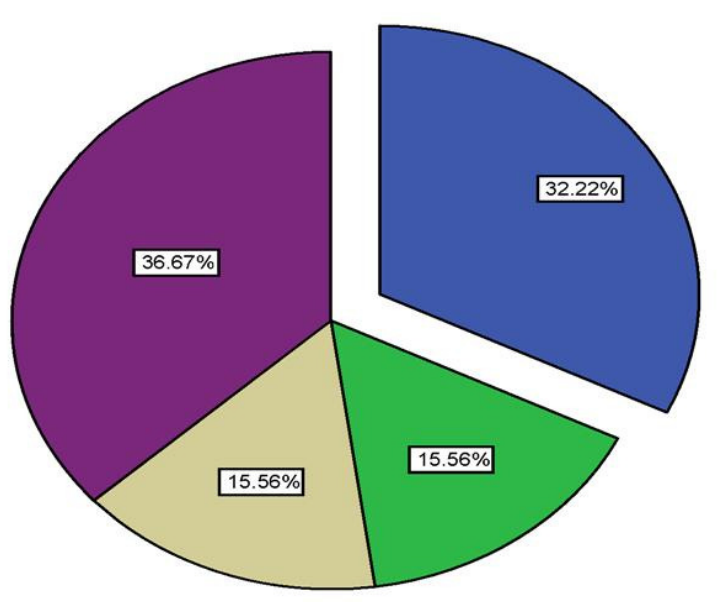

efforts (Smith, 1979). When asked what alternative livelihood strategies they propose in order to counteract the effects of falling fish catches, $36.67 \%$ of households suggested introduction of livestock farming while $15.56 \%$ said they would like to intensify agricultural activities and the same percentage suggested starting up private businesses (Figure 6).

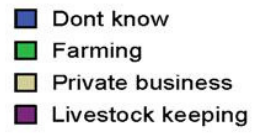

Figure 6 Respondents' suggested alternative livelihood to lessen pressure on marine resources

During focused group discussions, livestock keeping as the appropriate alternative livelihood strategy resurfaced frequently and was motivated by the increasing number of pastoralists that migrated into the area, mostly from Ihefu in Mbeya. According to them, before these pastoralists came into the area, the communities around Kilwa were reluctant to keep livestock because of the myth that the proximity of the area to Selous Game Reserve rendered the area vulnerable to tsetse fly, i.e., sleeping sickness (Personal communication; District Livestock Officer, 2010).

Coral Reef Conservation and Local communities Livelihood Trajectories: A Synthesis

During this survey, when the participants were asked to suggest ways for minimizing the 
rapidly diminishing Kilwa marine resources, $78.9 \%$ proposed establishment of core areas that would be closed to allow fish to breed and grow,

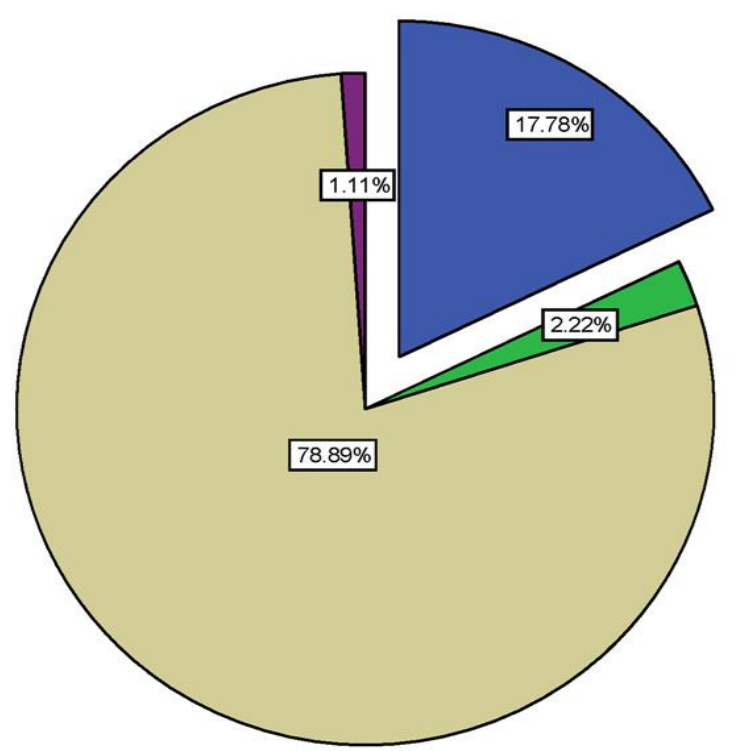

$2.2 \%$ proposed establishing community based management plan, and $1.1 \%$ proposed acquiring modern fishing gear (Figure. 7).

Figure 7 Respondents' proposed management initiatives for marine areas

A similarly move to establish Mafia and Ruvuma Estuary Marine resulted in gradual decline of destructive fishing practices that had previous threatened wiping out marine resources in these areas (Lindahl et al., 2001). Further studies show that establishing conservation area is an appropriate approach in dealing with issues related to resource decline (McClanahan and Kaunda-Arara, 1996). Furthermore, once a conservation area is established, in addition to creating resource use sustainability; it also empowers fishermen and other communities through improvement of social services schools, clean drinking water, dispensaries, and good roads. In line with the objectives of the Fisheries Policy of Tanzania (MNRT, 2003), the National Poverty Eradication Strategy intends to increase utilization of natural resources, including fisheries, to fight poverty (VP's Office, 1998). However, as observed above, the marine resources, including fisheries are diminishing at an alarming rate that if we urgently need to develop mechanisms for salvaging them. In order to achieve this, various factors must come into play; the most important are the communities who interact directly with their resources on a daily basis. Incorporating communities at initial stages is very important for them to have a sense of ownership of the planned management area (Coughanowr et al., 1995).

\section{Conclusion and Recommendations}

Various causes that range from human actions such as destructive fishing practices to natural acts such as climate change have already been affecting the coral reefs and many areas have died due to coral bleaching. This has had big impacts on many types of fish stocks and marine life, causing the stocks to decline. Unlike agriculture, products from the sea are available throughout the year. In addition, because of fluctuations in prices of agricultural products and unreliability of rains, agriculture is less popular in most areas including those located on the coastline. The observed continued decline of fishery catches necessitates the need for diversification of local livelihoods. Introduction of modern farming, especially such crops are tomatoes, green vegetables, legumes and fruits that involve irrigation in areas close to water sources may serve as important source of incomes to many as reliable markets are guaranteed in Dar es Salaam and other neighboring major cities. Though not yet perfected, widespread introduction and promotion of mud-crab (Scylla serrata) and milkfish (Chanos Chanos) farming specifically 
in mangrove may significantly contribute in diversifying livelihoods in the area. As a permanent solution to frequent coral reef degradation we recommend establishment of marine management area within the whole Kilwa coastline. Lastly, besides promotion of education programs on importance of reefs and the management techniques, we recommend application of low cost conservation practices such as restoration so as to reverse the badly denuded reefs to their original states.

\section{Acknowledgements}

This study was supported by grants from Research and Poverty Alleviation (Repoa) and the World Bank/GEF projects. We thank the Kilwa District officials for field facilitation and Christopher Mahonge for technical advice on data analysis.

\section{References}

Andersson, J. (1998), The Value of Coral Reefs for the Current and Potential Tourism Industry on Unguja Island, Zanzibar. In: Johnstone, R. W., Francis, J. \& Muhando, C. A. (eds.) Coral Reefs: Values, Threats, and Solutions. Proceedings of the National Conference on Coral Reefs, 2-4 December 1997, Zanzibar, Tanzania. Institute of Marine Sciences (University of Dar es Salaam). Zanzibar, Tanzania. pp. 82-90.

Boko M., I, Niang, A., Nyong, C., Vogel, A., Githeko, M., Medany, B., Osman-Elasha, R., Tabo, P., Yanda, (2007), Africa. Climate Change 2007: Impacts, adaptation and vulnerability. Contribution of Working Group II to the Fourth Assessment Report of the Intergovernmental Panel on Climate Change, ML Parry, OF Canziani, JP Palutikof, PJ van der Linden, CE Hanson (Eds.). Cambridge University Press, Cambridge UK, 433-467.

Coughanowr, C.A., M.N., Ngoile, O.L., Lindén, (1995), Coastal zone management in Eastern Africa and the island states: a review of issues and initiatives. Ambio 24, 448-457.

District Fisheries Statistics (2000 - 2009) Fishery Catches in all Fish Landing Sites of Kilwa. Pp89.

Francis, J., A., Nilsson, D., Waruinge, (2001), Marine Protected Areas in the Eastern African Region: How Successful are They? Ambio 31 (78), 503-511.

Garpe, K. C., M.C., Öhman, (2003), Coral and Fish Distribution Patterns in Mafia Island Marine Park, Tanzania: Fish-Habitat Interactions. Hydrobiologia 498, 191-211.
Guard, M., M., Masaiganah, (1997), Dynamite Fishing in Southern Tanzania, Geographical Variation, Intensity of Use and Possible Solutions. Mar. Poll. Bull. 34 (10): 758-762.

WWF/RUMAKI., 2000-2008 Collaborative Fisheries Management (CFM) Monitoring Plans for Rufiji, Mafia, Kilwa Fishing communities.

Jiddawi, N. (1997), The Reef Dependent Fisheries of Zanzibar. In: Johnstone, R., Francis, J. and Muhando C.A. Proceedings of the National Conference on Coral Reefs, December 1997, Zanzibar Tanzania. P 22-35.Jiddawi, N.S and Stanley, R. (eds.) 1997. Fisheries Stock Assessment in the traditional Fishery Sector: The information needs. Proceedings of the National Workshop on the Artisanal Fisheries Sector. September 1997, Zanzibar. IMS. 192 pp.

Jiddawi, N. S., M.C., Öhman, (2002), Marine Fisheries in Tanzania. Ambio 31 (7-8): 518527Johnstone. R. W., Francis, J. and Muhando, C.A. (eds.) 1998b. Coral Reefs: Values, threats and solutions. Proceedings of the National (IYOR) Conference on Coral Reefs, Zanzibar, Tanzania. Institute of Marine Sciences, Zanzibar. 124 pp.

Lindahl, U., M.C., Öhman, Schelten, C. K., (2001), The 1997/1998 Mass Mortality of Corals: Effects on Fish Communities on a Tanzanian Coral Reef. Mar. Poll. Bull. 42(2), 127-131.

Mbije, N.E., G.W., Wagner, J., Francis, M.C., Öhman, K.C., Bergman, K. C. (2002), Patterns in the Distribution and Abundance of Hard Corals Around Zanzibar Island. Ambio 31 (7-8), 609-611.

Mbije, N.E.J., E., Spanier, B., Rinkevich, (2010), Testing the First Phase of Gardening Concept as Applicable Tool in Restoring Denuded Reefs of Tanzania. Ecol. Eng. 36 (2010), 713-721.

McClanahan T.R., B., Kaunda-Arara. (1996), Fishery recovery in a coral-reef marine park and its effect on the adjacent fishery. Conservation Biology 10, 1187-1199.

McClanahan, T.R. (1997), Predation, Distribution and Abundance of Tropical Sea Urchin Populations. J. Exp. Mar. Biol. Ecol. 221, 231-255.

McClanahan, T.R., N.A., Muthiga, , A.T., Kamukuru, H., Machano, R.W., Kiambo, (1999), The Effects of Marine Parks and Fishing on Coral Reefs of Northern Tanzania. Biological Conservation. 89, 161-182.

Mwichande, B.S. (2001), The description of Marine and Coastal Areas of Kilwa District Based on the IUCN Criteria for Site Selection. 
Report submitted to Pew Country Operation Team, Dar es Salaam. 51 pp.

Ngoile, M.A.K., A., Mwamsojo, F.J., Kaiza, (2001), Kilwa; Paradise lost. Pew Fellowship Program. 43pp.

National Bureau of Statistics (1999) 1998 Population Census. A Preliminary Report.

Smith, I. R., 1979. Traditional fisheries development in the Philippines. ICLARM Newsletter.

July 1979. pp. 16-18.

Wagner, G.M. (2004), Coral reefs and their management in Tanzania. Western Indian Ocean Journal and Marine Science 3, 227-243.

Wagner, G.M. (2005), Coral reefs. In: Tanzania Coastal Management Partnership. Tanzania State of the Coast Report 2003: The National ICM Strategy and Prospects for Poverty Reduction. Tanzania Coastal Management Partnership, Dar es Salaam: 1-4.

Wilkinson C.R. (2004) Status of Coral Reefs of the World: 2002. Australian Institute of Marine Science. 331pp.

Coral crisis 2011. www.mongabay.com/2010/1110-

hance_beyondgloom.html. Cited on 20th July 2011 at 20hours East African time.

URT, 1999. The Village Land Act No. 5.

URT, 2005. Poverty Reduction Strategy Paper (accessed at http://www.imf.org/external/NP/prsp/2000/tza/0 2/) 